\title{
Recurrent Hypoglycaemia in a Case of Phyllodes Tumour of the Breast: A Rare Case Report
}

Kumar Kar S*, Choudhuri R, Bhunia P, Chakrabarti S and Santra S

Department of Anaesthesiology \& Cardiac Anaesthesiology, Institute of Post Graduate Medical Education \& Research, Kolkata, India

*Corresponding author: Sandeep Kumar Kar, Department of Cardiac Anaesthesiology, Institute of Postgraduate Medical Education \& Research, Kolkata, India, Tel: +919477234900; Email: sndpkar@yahoo.co.in

Received date: March 22, 2016; Accepted date: April 28, 2016; Published date: April 29, 2016

Copyright: (c) 2016 Kumar Kar S, et al. This is an open-access article distributed under the terms of the Creative Commons Attribution License, which permits unrestricted use, distribution, and reproduction in any medium, provided the original author and source are credited.

\begin{abstract}
Phyllodes tumors are fibroepithelial neoplasms that represents less than $1 \%$ of all breast tumors and are usually found in middle-aged women. The combination of this tumor along with hypoglycemia is very rare. The perioperative management of hypoglycemia in those cases is also quite difficult. Here, we are presenting a challenging case of phyllodes tumor of the breast associated with hypoglycemia, and perioperative management of hypoglycemia.
\end{abstract}

Keywords: Fibroepithelial neoplasm; Neuroendocrine tumor; Nonislet cell tumor-induced hypoglycaemia; Perioperative management

\section{Introduction}

Phyllodes tumor (from Greek: phullon leaf) was originally described by Chelius in 1827 [1] and first named by Johannes Muller in 1838. Phyllodes tumors are a fibroepithelial tumor composed of an epithelial and a cellular stromal component. They may be benign, borderline, or malignant depending on histologic features including stromal cellularity, infiltration at the tumor's edge, and mitotic activity. All forms of phyllodes tumors are considered to have malignant potential. This is predominantly a tumor of adult women, with very few examples reported in adolescents (although there are case reports in men, especially if previously associated with gynaecomastia). Phyllodes tumors account for about $0.3 \%-0.5 \%$ of all female breast tumors [2]. Patients typically present with a firm, palpable mass. These tumors are very fast-growing, and can increase in size in just a few weeks. The median size of tumor is $4-7 \mathrm{~cm}$, and it may cause fatigue, dyspnoea, and bone pain in metastatic disease. $20 \%$ tumours can grow larger than $10 \mathrm{~cm}$. Tumours can also grow larger than $40 \mathrm{~cm}$ [3]. Occurrence is most common between the ages of 45 and 49 [4,5], prior to menopause. This is older than the typical age of patients with fibroadenoma, with which phyllodes tumors may be confused.

Non-islet cell tumor-induced hypoglycemia (NICTH), although more commonly associated with other mesenchymal tumors, is a rare paraneoplastic sequel of phyllodes tumor. Phyllodes tumors associated with non-islet cell tumor-induced hypoglycemia usually grows to greater than $10 \mathrm{~cm}$. This tumor leading to non-islet cell tumor-induced hypoglycemia may develop over several years or even rapidly. The common treatment for phyllodes tumor is wide local excision [6]. Chemotherapy and radiation therapy are not effective for this tumor. The risk of developing local recurrence or metastases is related to the histologic grade. Despite wide excision, a very high percentage of surgeries yielded incomplete excision margins that required revision surgery [7]. Complete excision of the tumor with continued follow-up is key to management. Here we report a case of phyllodes tumor presenting with non-islet cell tumor-induced hypoglycemia posted for surgery, along with the management of hypoglycemia and perioperative managements in intensive care.

\section{Case Summary}

A 38 year old non-diabetic, non-hypertensive female patient had an episode of drowsiness followed by brief unconsciousness on the morning of 9th august 2015. Patient was arousable after 10 minutes of unconsciousness and her relatives rushed her to a local nursing home. She was given intravenous fluids and she could move her limbs and her body normally. She had no slurring of speech, deviation of angle of mouth, loss of voluntary control of micturition and defecation, fever, sore throat, shortness of breath, palpitation or chest pain. While being shifted to intensive therapy unit (ITU) of Institute of Post Graduate Medical Education and Research \& Seth Sukhlal Karnani Memorial hospital (IPGMER\&SSKMH) Kolkata, she became fully conscious and oriented. CT-Scan of brain was done immediately which was absolutely normal. Arterial blood gas analysis was unremarkable. Her capillary blood glucose (CBG) revealed a level of $57 \mathrm{mg} / \mathrm{dl}$, but the patient seemed to have no symptoms of hypoglycemia. She was given two $100 \mathrm{ml}$ bottles of $25 \%$ dextrose over 15 minutes each. CBG after 1 hour revealed $113 \mathrm{mg} / \mathrm{dl}$. Her routine blood tests were normal. She was put on normal diet and kept under strict CBG monitoring. Chest X-ray PA view was done next day which was normal. The patient continued to have repeated episodes of hypoglycemia over the next few day with CBG readings as low as $19 \mathrm{mg} / \mathrm{dl}, 27 \mathrm{mg} / \mathrm{dl}, 29 \mathrm{mg} / \mathrm{dl}$ especially during 3 am to 6 am in the mornings.

She was put under strict monitoring of heart rate, spo2, respiratory rate and blood pressure but these came out to be normal limit. Since she was having repeated hypoglycemic attacks in spite of adequate normal diet, she was put on infusion $25 \%$ dextrose $100 \mathrm{ml} 4$ hourly from 13th august, 2015. After that her blood glucose stabilised with levels $>90 \mathrm{mg} / \mathrm{dl}$. An endocrine referral was done and she was advised several tests like fasting cortisol, insulin antibody, insulin, serum cpeptide during hypoglycemic attacks, thyroid stimulating hormones(TSH), free thyroid hormones (fT4, fT3). Thyroid profile, fasting serum cortisol and insulin antibody level were within normal range. But Serum c-peptide value was $0.18 \mathrm{ng} / \mathrm{ml}$ (normal level $\rightarrow 1.1-4.4 \mathrm{ng} / \mathrm{ml}$ ) and serum insulin level was $0.68 \mathrm{miu} / \mathrm{L}$ (normal level 
$\rightarrow 2.6-24.9 \mathrm{miu} / \mathrm{L})$. So, those values were low during hypoglycemic attack. This patient had a history of morning sweating, flushing of body and drowsiness for the last 15 days before admission which got relieved with taking little food. On 2 nd august she had a history of similar conditions followed by unconsciousness which was transient about 20 seconds and she was relieved by glucose drinks. The patient also had a past history of phyllodes tumor of right breast for the last 1 year under investigations \& the tumor was increasing in size for last 6 months. All reports including bone scan, USG whole abdomen, CECT thorax, core biopsy and routine of last year were normal. A general surgery referral was done and she was advised CECT chest and abdomen which came out to be normal except for phyllodes tumor in CECT chest. The possibility of phyllodes tumor causing hypoglycemic attacks was thought of and she was planned for modified radical mastectomy (MRM) with stage 1 lymph node dissection on 19th august, 2015 (Figure 1).

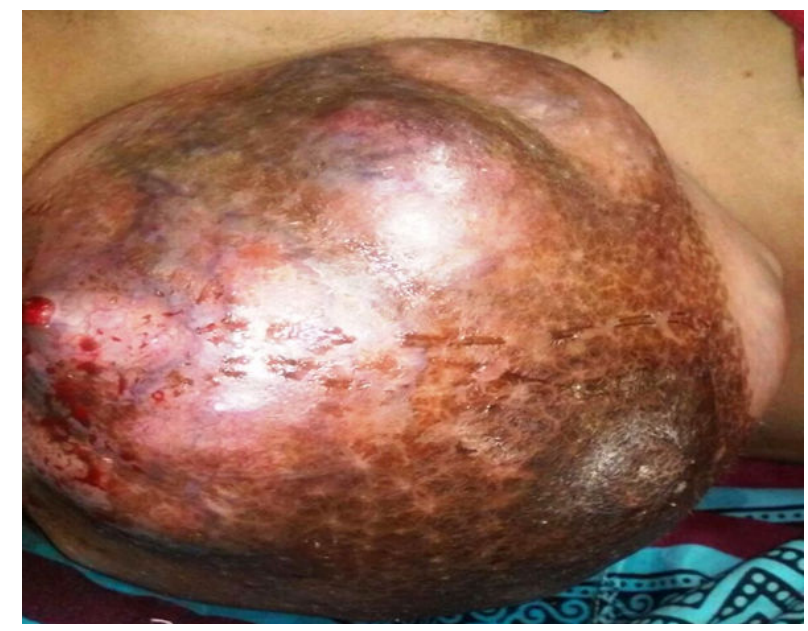

Figure 1: Right breast mass impending to rupture.

For management of perioperative hypoglycemia, she was advised inj. octreotide $50 \mu \mathrm{g} \mathrm{s} / \mathrm{c} 8$ hourly upto 2 hours before OT, intravenous fluid 5\% dextrose $(500 \mathrm{ml}) 8$ hourly, $25 \%$ dextrose $(100 \mathrm{ml}) 6$ hourly and sos, inj hydrocortisone $50 \mathrm{mg}$ i.v. 8 hourly and glucagon challenge test was done which showed hypoglycemia was responsive to glucagon. Her operation was done with excision of a $4 \mathrm{~kg}$ mass from the right breast under general anesthesia with strict control of CBG. In operating room, premedication was given with inj. Glycopyrrolate $(0.01 \mathrm{mg} / \mathrm{kg})$, fentanyl $(2 \mathrm{mcg} / \mathrm{kg})$ and induction was done with inj. Thiopentone $(5 \mathrm{mg} / \mathrm{kg}$ ) and as muscle relaxant atracurium (loading dose- $0.5 \mathrm{mg} / \mathrm{kg}$ ) was used. Maintenance was done with propofol, nitrous oxide and isoflurane $1-2 \%$. Fluid management intraoperatively was done with crystalloids and maintenance $10 \%$ dextrose given slowly $100 \mathrm{ml} / \mathrm{hr}$ to prevent hypoglycemia. Intraoperatively CBG monitoring was done half hourly. Intraoperative period was uneventful with stable hemodynamics and minor fluctuations in blood glucose level. She was extubated after the operation.

After operation her blood glucose started stabilising with most values $>150 \mathrm{mg} / \mathrm{dl}$. 25\% dextrose infusion was gradually tapered off and ultimately stopped on postoperative third day. Now she could maintain her CBG with her normal diet only. Histopathological examination revealed large phyllodes tumor $(23 \mathrm{~cm} \times 19 \mathrm{~cm} \times 14 \mathrm{~cm})$ which was benign in origin \& all nine level 1 axillary lymph nodes were reactive.
The routine laboratory investigations were unremarkable. Postoperative IGF1, IGF2 levels were measured and compared with preoperative value suggestive of non islets cell tumor induced hypoglycaemia (Table 1).

\begin{tabular}{|l|l|l|l|}
\hline Parameters & Reference range & Preoperative & Postoperative \\
\hline Insulin antibody & $<12 \mathrm{U} / \mathrm{ml}$ & $1.7 \mathrm{U} / \mathrm{ml}$ & not done \\
\hline IGF 1 & $90-284 \mathrm{ng} / \mathrm{ml}$ & $66.4 \mathrm{ng} / \mathrm{ml}$ & $174.6 \mathrm{ng} / \mathrm{ml}$ \\
\hline IGF 2 & $288-716 \mathrm{ng} / \mathrm{ml}$ & $732.6 \mathrm{ng} / \mathrm{ml}$ & $390.2 \mathrm{ng} / \mathrm{ml}$ \\
\hline IGF2/IGF1 & $<10$ & 11.03 & 2.23 \\
\hline
\end{tabular}

Table 1: Comparison of intraoperative and postoperative Insulin antibody, IGF $1 \& 2$.

\section{Discussion}

In rare cases large phyllodes tumors can present with hypoglycemia. This case highlights the diagnosis and management of non-islet cell tumour-induced hypoglycemia caused by phyllodes tumor and perioperative anaesthetic management. Hypoglycemia is a common medical problem in patients with diabetes mellitus. Hypoglycemia is also associated with gastric bypass surgery [8]. Although rare, hypoglycemia is occasionally encountered in nondiabetic, nongastric bypass patients where hypoglycemia is usually a manifestation of pancreatic islet cell tumors producing insulin, primary or secondary adrenal insufficiency, pheochromocytoma, IGF1 secreting tumors, hypothyroidism, nonislet cell tumor induced hypoglycemia (NICTH) or antibodies interfering with insulin receptors. In patients with recurrent hypoglycemia and no history of diabetes or weight loss surgery, non-islet cell tumour-induced hypoglycemia may be the underlying cause. Malignancies associated with insulin receptor antibodies, tumor necrosis factor (TNF) and tumors like pheochromocytoma, solitary fibrous tumors (independent of anatomical location), wilm's tumors, metastatic hemangiopericytomas, mesotheliomas, hepatocellular carcinomas, gastrointestinal stromal tumors (GIST), colorectal-adenomas, osteosarcomas, rhabdomyosarcomas, leiomyosarcomas, paragangliomas, prostate cancers, breast cancers are known to cause non-islet cell tumorinduced hypoglycaemia $[9,10]$.

Non-islet cell tumor-induced hypoglycemia is a paraneoplastic process and tumors that cause hypoglycemia are generally greater than $10 \mathrm{~cm}$ in diameter. Hypoglycemia can occur in both fasting and nonfasting state by multiple mechanisms. Hypoglycemia results from inhibited hepatic glycogenolysis, gluconeogenesis and diminished lipolysis in adipose tissue. Hypoglycemia here indicates increased insulin-like activity in the body. Hypoglycemia may also occur due to increased glucose utilization by the cells of large tumor. However the $\beta$-hydroxybutyrate level is usually low and the glucose response to glucagon stimulation is normal in these cases, showing that this is not a normal cause of hypoglycemia responding to glucagon [11]. It is now proved that IGF is a key factor in the pathogenesis of non-islet cell tumor-induced hypoglycaemia [12-14].

The IGF-2 gene is situated on short arm of chromosome 11 (11p15) near the insulin (INS) gene. IGF-2 is normally a $7.5-\mathrm{kDa}$ peptide, but in cases of NICTH, IGF-2 has high molecular weight (10- to $20-\mathrm{kDa})$ $[15,16]$. Mature IGF-2 is synthesized from a 180 amino acid preprohormone having a C-terminal extension of 89 amino acids known as the E-domain in the immature stage. During intracellular 
processing the E-domain is cleaved, resulting in mature IGF-2, which if not cleaved from pro IGF-2 results in big IGF2. Normally in plasma $<10 \%$ of circulating IGF-2 is big IGF-2. Under physiologic conditions, IGF-2 is mainly produced by the liver. But several malignancies (like sarcomas) can produce large amounts of big IGF-2 [16] leading to a large amount of big IGF-2 at the level of target tissues. Mature IGF-2 has $47 \%$ sequence match with insulin, and also active biochemically, hence stimulates glucose metabolism pathways which leads to hypoglycaemia $[15,17]$. On the other hand, suppression of growth hormone occurs at pituitary gland by negative feedback mechanism which causes decrease in IGF-1level. Therefore increased IGF-2/IGF-1 ratio points to the diagnosis of IGF2 producing NICTH.

Unlike IGF-1, IGF-2 regulation is independent of growth hormone influence [18]. IGF-1and IGF-2 both have hypoglycemic potential which is approximately $5 \%$ of insulin's potency. Plasma concentrations of IGF-1and IGF-2 can be 1000 times greater than insulin in NICTH permitting them to cause hypoglycemia [19]. More than $95 \%$ of IGF-2 in the circulation is bound to insulin like growth factor binding proteins (IGFBP) [20]. At the cellular level, IGF-2 binds with IGF-2 receptor which mediates functions like endocytosis, intracellular hormone transport and metabolism of circulating IGF-2 [21]. On the contrary, there are several reports of neoplasms having high levels of IGF-2 mRNA without exhibiting elevated hormone activity [22,23].

In this case, the pre-excision IGF- 1 was $66.4 \mathrm{ng} / \mathrm{ml}$ which is low and IGF-2 level was $732.6 \mathrm{ng} / \mathrm{ml}$ which is towards higher level of normal range. But after surgery, both IGF-1 (174.6 ng/ml) and IGF-2 (390.2 $\mathrm{ng} / \mathrm{ml}$ ) level were within the normal range. The pre-operative IGF-2/ IGF-1 ratio was $11.03($ normal<10) suggesting NICTH. The post excision IGF-2/IGF-1 ratio was 2.23 which further strengthened our diagnosis. This patient was suffering from recurrent hypoglycaemic attacks in spite of normal diet which was managed by continuous administration of dextrose containing fluids. Once the tumor is identified, its excision is the mainstay of treatment and complete resection leads to rapid resolution of hypoglycemia. After removal of the tumor, the blood sugar level normalises and the IGF-2 level decreases, as seen in this case [6].

Endogenous hyperinsulinism and insulinomas come in close differential diagnosis with NICTH and needs to be identified. Endogenous hyperinsulinism can be caused by a primary beta-cell tumor, an antibody to insulin receptor or ectopic insulin secretion. This is diagnosed by measuring plasma insulin and c-peptide level during period of hypoglycemia. The findings in endogenous hyperinsulinism are plasma insulin $>3 \mu \mathrm{u} / \mathrm{ml}$, c-peptide $>0.6 \mathrm{ng} / \mathrm{ml}$ with plasma glucose $<55 \mathrm{mg} / \mathrm{dl}$ and symptoms of hypoglycemia. Insulinomas are insulin secreting pancreatic beta cell tumors. They are benign and a rare form of neuroendocrine tumor. They are a treatable cause of fatal hypoglycemia. The median age at presentation is in the third decade of life as part of multiple endocrinal neoplasia (MEN-1). CT or MRI detects approximately $70-80 \%$ of insulinomas, as well as metastasis in malignant insulinomas [24]. These were excluded easily in this patient by relevant laboratory investigations.

\section{Conclusion}

We reported a middle aged female patient with large right sided breast mass who underwent modified radical mastectomy with level 1 lymph node dissection. Histopathological examination suggested of a benign phyllodes tumor. The patient had symptomatic hypoglycemia secondary to her phyllodes tumor which suggested to non-islet cell tumor-induced hypoglycemia. This hypoglycemia was corrected after removal of the tumor.

\section{References}

1. Chelius M. Neue Jahrbucher Der Teutschen Medicin and Chirurgie. Heidelberg, Germany: Naegele und Puchelt; 1827.

2. Rowell MD, Perry RR, Hsiu JG, Barranco SC (1993) Phyllodes tumors. Am J Surg 165: 376-379.

3. Reinfuss M, MituÅ> J, Duda K, Stelmach A, RyÅ> J, et al. (1996) The treatment and prognosis of patients with phyllodes tumor of the breast: an analysis of 170 cases. Cancer 77: 910-916.

4. Salvadori B, Cusumano F, Del Bo R, Delledonne V, Grassi M, et al. (1989) Surgical treatment of phyllodes tumors of the breast. Cancer 63: 2532-2536.

5. Bernstein L, Deapen D, Ross RK (1993) The descriptive epidemiology of malignant cystosarcoma phyllodes tumors of the breast. Cancer 71 : 3020-3024.

6. Tan BY, Acs G, Apple SK, Badve S, Bleiweiss IJ, et al. (2016) Phyllodes tumours of the breast: a consensus review. Histopathology 68: 5-21.

7. Moffat CJ, Pinder SE, Dixon AR, Elston CW, Blamey RW, et al. (1995) Phyllodes tumours of the breast: a clinicopathological review of thirtytwo cases. Histopathology 27: 205-218.

8. Vella A, Service FJ (2007) Incretin hypersecretion in post-gastric bypass hypoglycemia--primary problem or red herring? J Clin Endocrinol Metab 92: 4563-4565.

9. de Groot JW, Rikhof B, van Doorn J, Bilo HJ, Alleman MA, et al. (2007) Non-islet cell tumour-induced hypoglycaemia: a review of the literature including two new cases. Endocr Relat Cancer 14: 979-993.

10. Jones JI, Clemmons DR (1995) Insulin-like growth factors and their binding proteins: biological actions. Endocr Rev 16: 3-34.

11. Pacioles T, Seth R, Orellana C, John I, Panuganty V, et al. (2014) Malignant phyllodes tumor of the breast presenting with hypoglycemia: a case report and literature review. Cancer Manag Res 6: 467-473.

12. Zapf J (1993) Role of insulin-like growth factor (IGF) II and IGF binding proteins in extrapancreatic tumour hypoglycaemia. J Intern Med 234: 543-552.

13. Chung J, Henry RR (1996) Mechanisms of tumor-induced hypoglycemia with intraabdominal hemangiopericytoma. J Clin Endocrinol Metab 81: 919-925.

14. Hizuka N, Fukuda I, Takano K, Okubo Y, Asakawa-Yasumoto K, et al. (1998) Serum insulin-like growth factor II in 44 patients with non-islet cell tumor hypoglycemia. Endocr J 45 Suppl: S61-65.

15. Bell GI, Gerhard DS, Fong NM, Sanchez-Pescador R, Rall LB (1985) Isolation of the human insulin-like growth factor genes: insulin-like growth factor II and insulin genes are contiguous. Proc Natl Acad Sci U S A 82: 6450-6454.

16. Daughaday WH, Emanuele MA, Brooks MH, Barbato AL, Kapadia M, et al. (1988) Synthesis and secretion of insulin-like growth factor II by a leiomyosarcoma with associated hypoglycemia. N Engl J Med 319: 1434-1440.

17. Baxter RC (1996) The role of insulin-like growth factors and their binding proteins in tumor hypoglycemia. Horm Res 46: 195-201.

18. O'Dell SD, Day IN (1998) Insulin-like growth factor II (IGF-II). Int J Biochem Cell Biol 30: 767-771.

19. Alkemade GM, Bakker M, Rikhof B, IJpma FF, van Ginkel RJ, et al. (2013) Hypoglycemia in a patient with a big "big"-IGF-II-producing tumor. J Clin Endocrinol Metab 98: 3113-3114.

20. Hoekman K, van Doorn J, Gloudemans T, Maassen JA, Schuller AG, et al. (1999) Hypoglycaemia associated with the production of insulin-like growth factor II and insulin-like growth factor binding protein 6 by a haemangiopericytoma. Clin Endocrinol (Oxf) 51: 247-253.

21. Butler AA, Le Roith D (2001) Control of growth by the somatropic axis: growth hormone and the insulin-like growth factors have related and independent roles. Annu Rev Physiol 63: 141-164. 
Citation: Kumar Kar S, Choudhuri R, Bhunia P, Chakrabarti S, Santra S (2016) Recurrent Hypoglycaemia in a Case of Phyllodes Tumour of the Breast: A Rare Case Report. J Carcinog Mutagen 7: 264. doi:10.4172/2157-2518.1000264

Page 4 of 4

22. Han VK, D'Ercole AJ, Lund PK (1987) Cellular localization of somatomedin (insulin-like growth factor) messenger RNA in the human fetus. Science 236: 193-197.

23. Humbel RE (1990) Insulin-like growth factors I and II. Eur J Biochem 190: $445-462$.
24. Philip E. Cryer, Stephen N. Davis (2012) Hypoglycemia. Harrison's Principles of Internal Medicine, 18th edn 2: 3003-3009. 